\title{
BIOCOMPOSITES FROM TANNED LEATHER FIBRES WITH APPLICATIONS IN CONSTRUCTIONS
}

\author{
Gabriel ZĂINESCU ${ }^{1 *}$, Viorica DESELNICU ${ }^{1}$, Roxana CONSTANTINESCU ${ }^{1}$, Dan GEORGESCU ${ }^{2}$ \\ ${ }^{1}$ INCDTP - Division: Leather and Footwear Research Institute, 93 Ion Minulescu st., 031215, Bucharest, Romania, e-mail: \\ icpi@icpi.ro
}

${ }^{2}$ Technical University of Civil Engineering of Bucharest, 122-124 Bd. Lacul Tei, 020396, Bucharest, Romania

Received: 07.06.2018 Accepted: 07.09.2018 https://doi.org/10.24264/Ifj.18.3.4

\begin{abstract}
BIOCOMPOSITES FROM TANNED LEATHER FIBRES WITH APPLICATIONS IN CONSTRUCTIONS
ABSTRACT. In tanneries, only approx. one-third of the total mass of raw hides and skins is converted to finished leather, while two-thirds become either dissolved or solid waste. As part of the natural materials category, usually considered waste, leather fibers introduced into cement mortar panels play a fundamental role in construction due to both insulation properties and mechanical strength. Waste is introduced as a powder or filler or as aggregates in the concrete mix, with energy, economic and environmental benefits. The originality and innovative contribution of the scientific paper consists in re-evaluation of tanned leather waste from the leather sector by turning them into raw materials with added value and using them in construction materials industry, by developing new production concepts for new biocomposite materials. KEY WORDS: tanned leather fibres, biocomposites, Portland cement
\end{abstract}

\section{BIOCOMPOZITE DIN FIBRE DE PIELE TĂBĂCITĂ CU APLICATII ÎN CONSTRUCTII}

REZUMAT. În tăbăcării, doar cca. o treime din masa totală a pieilor brute de animale mari şi mici este transformată în piele finită, în timp ce două treimi devin fie deşeuri dizolvate, fie solide. Făcând parte din categoria materialelor naturale, considerate de obicei deşeuri, fibrele de piei introduse în panouri din mortar de ciment, joacă un rol fundamental în construcţii datorită atât proprietăţilor de izolare, cât şi de rezistenţă mecanică. Deşeurile sunt introduse ca pulbere sau umplutură sau ca agregate în amestecul de beton, avand avantaje din punct de vedere energetic, economic şi de protecţie a mediului. Originalitatea şi contribuţia inovatoare a lucrării ştiinţifice constă în reevaluarea deşeurilor din piele tăbăcită din sectorul de pielărie prin transformarea acestora în materii prime cu valoare adăugată şi prin utilizarea în industria materialelor de construcţie prin dezvoltarea unor noi concepte de producţie pentru materiale biocompozite noi.

CUVINTE CHEIE: fibre de piele tăbăcită, biocompozite, ciment Portland

\section{BIOCOMPOSITES DE FIBRES DE CUIR AVEC APPLICATIONS DANS L'INDUSTRIE DE LA CONSTRUCTION}

RÉSUMÉ. Dans les tanneries, seulement env. un tiers de la masse totale des peaux bruts est converti en cuir fini, tandis que deux tiers deviennent des déchets solides ou dissous. Faisant partie de la catégorie des matériaux naturels, généralement considérés comme des déchets, les fibres de cuir introduites dans les panneaux de mortier de ciment jouent un rôle fondamental dans la construction en raison à la fois des propriétés d'isolation et de la résistance mécanique. Les déchets sont introduits sous forme de poudre ou de charge ou sous forme d'agrégats dans le mélange de béton, avec des avantages énergétiques, économiques et environnementaux. L'originalité et la contribution innovante de l'article scientifique consistent à réévaluer les déchets de cuir tannés du secteur du cuir en les transformant en matières premières à valeur ajoutée et en les utilisant dans l'industrie des matériaux de construction pour développer de nouveaux concepts de production pour de nouveaux matériaux biocomposites.

MOTS CLÉS : fibres de cuir, biocomposites, ciment Portland

\section{INTRODUCTION}

The leather processing industry has made significant efforts in recent years on the improved efficiency in using energy and materials, as well as in discarding the use of hazardous materials in production phases [1]. Solid waste (from raw hide and tanned leather, residual wool and sludge from wastewater treatment) is a significant issue of the leather sector [2-3].
Nowadays, the cement industry is responsible for $5-7 \%$ of global $\mathrm{CO}_{2}$ emissions. To reduce them, new technological solutions and new building materials have recently been developed to protect natural resources. Thus, the concept of "green" materials involved both natural fibers and a large amount of waste. Natural fibers are used to improve the mechanical performance of cement-based composites instead of synthetic ones (e.g.

\footnotetext{
* Correspondence to: Gabriel ZĂINESCU, INCDTP - Division Leather and Footwear Research Institute, 93 Ion Minulescu St., sector 3, Bucharest, Romania, icpi@icpi.ro
} 
PVA or polypropylene) as they provide greater tensile strength, ductility and post-cracking behavior and, at the same time, are increasingly appreciated due to their specific properties, low prices, health benefits and recyclability.

A ton of wet salted hide produces over $100 \mathrm{~kg}$ of waste of tanned leather waste [4]. The leather shaving process is done in tanneries in order to obtain a uniform leather thickness, but due to its low specific weight, a large amount of waste is accumulated in tanneries.

The paper presents the obtaining of biocomposites using leather shavings, with application in constructions. Three types of biocomposites were obtained by mixing $1 \%$ of 3 types of leather fibers: leather fibers treated with concentrated sulfuric acid (FPA); leather fibers neutralized with calcium hydroxide (FPN) and leather fibers immersed in a polymer binder (FP) with common Portland cement commercially known as Structo Plus ${ }^{\circledR}$.

\section{EXPERIMENTAL PART}

\section{Materials and Methods}

Leather shavings used in this work comes from the shaving process of $35 \mathrm{~kg}$ of hides from the SC PIELOREX SA tannery in Jilava, Ilfov County.

Leather shavings were chemically treated to immobilize the chromium ion in the common Portland cement matrix.

\section{Obtaining of Leather Fibers}

Tanned leather waste (shaving and small pieces) was defibrated with a knife mill used in the rubber industry, resulting in about $100 \mathrm{~kg}$ of tanned leather fibers. $600 \mathrm{~g}$ of leather fibers were hydrolyzed with $2 \%$ concentrated sulfuric acid solution at $80^{\circ} \mathrm{C}$ for 60 minutes resulting in FPA fibers. Then some of these fibers were neutralized with a $10 \%$ sodium hydroxide solution, so the $\mathrm{pH}$ increased from 1.78 to 6.12 (FPN fibers). Also, $330 \mathrm{~g}$ of leather fibers were immersed in a $3.5 \%$ polymer binder solution used in the pulp and paper industry (FP fibers).

Table 1 shows the physicochemical analyses of leather fibers treated with concentrated sulfuric acid and neutralized with calcium hydroxide (FPA and FPN).

Table 1: Physicochemical characterisation of tanned leather fibres

\begin{tabular}{|c|c|c|c|c|c|}
\hline \multirow[t]{2}{*}{ No. } & \multirow[t]{2}{*}{ Characteristics } & \multirow[t]{2}{*}{ UM } & \multicolumn{2}{|c|}{$\begin{array}{c}\text { Sample code/ } \\
\text { determined values }\end{array}$} & \multirow[t]{2}{*}{ Method standard } \\
\hline & & & FPA & FPN & \\
\hline 1 & Dry substance & $\%$ & 8.53 & 12.12 & SR EN ISO $4684: 2006$ \\
\hline 2 & Ash & $\%$ & 18.29 & 21.70 & SR EN ISO 4047 : 2002 \\
\hline 3 & Total nitrogen & $\%$ & 12.66 & 12.71 & SR ISO 5397 : 1996 \\
\hline 4 & Dermal substance & $\%$ & 71.15 & 71.43 & SR ISO 5397 : 1996 \\
\hline 5 & Chromium oxide & $\%$ & 5.16 & 4.37 & SR EN ISO 5398/1:2008 \\
\hline 6 & $\mathrm{pH}$ & $\mathrm{pH}$ unit & 1.78 & 6.12 & STAS 8619/3:1990 \\
\hline 7 & Calcium oxide & $\%$ & 0.23 & 0.25 & \\
\hline
\end{tabular}

\section{Obtaining of Biocomposites}

In the laboratory phase, cement composites reinforced with tanned leather fibers were obtained at a content of $1 \%$ by weight (replacing cement with leather fibers) which have been studied physically and mechanically.

The biocomposites were made by mixing $1 \%$ leather fibres with composite additivated Portland cement (Structo Plus ${ }^{\circledR}$ ). This cement is made in Romania for residential and commercial buildings, interior and exterior elements (paving blocks) and contains a component (Duraditiv ${ }^{\circledR}$ ) whose action improves the properties of concrete ensuring durability of the final product.

\section{Physicomechanical Characterisation of Biocomposites with Leather Fibres and Portland Cement}

Characterisation of biocomposites was conducted at the Technical University of Civil Engineering of Bucharest (UTCB). 
Determination of mechanical strengths (compressive and flexural strength) was conducted according to the following standards: STAS 4606-1980 «Natural heavy weight aggregates for mortars and concrete with mineral binding material. Testing methods», and EN 196-1:2016 «Methods of testing cement. Determination of strength».

The samples were made in metal moulds of $40 \times 40 \times 160 \mathrm{~mm}$ on solid brick, according to STAS 2634-80. The samples were evaluated after 7 and 28 days in terms of physicomechanical properties (compressive and flexural strength).

Compressive strength of biocomposites was determined after 7 and 28 days and results were compared with the control containing only cement. Charts are the average of 3 determinations of compressive strength.

\section{RESULTS AND DISCUSSIONS}

The analysis of experimental data showed that the values of compressive strength of FPA, FPN and FP biocomposites are higher compared to the control sample (without leather fibers), after 7 days, by $36 \div 48,7 \%$, and after 28 days, they are $11,6 \div 13,2 \%$ higher. (Fig. 1 and 2)

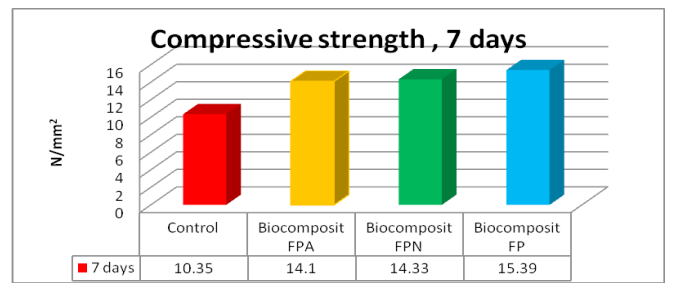

Figure 1. Compressive strength of biocomposites after 7 days

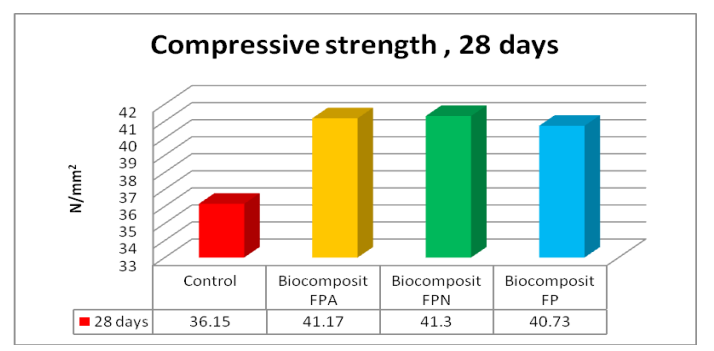

Figure 2. Compressive strength of biocomposites after 28 days

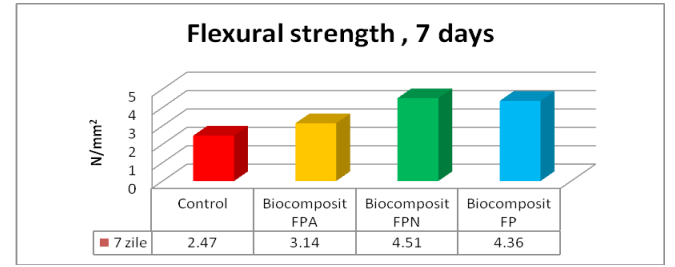

Figure 3. Flexural strength of biocomposites after 7 days

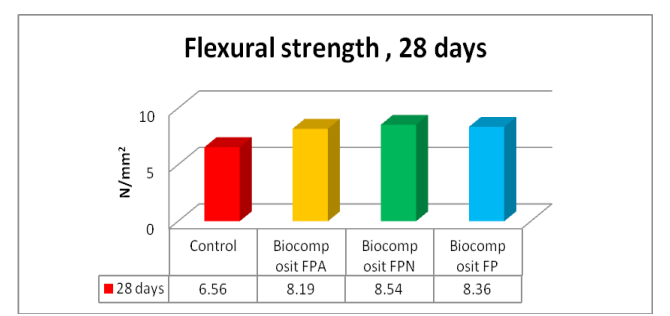

Figure 4. Flexural strength of biocomposites after 28 days

Flexural strength of biocomposites was determined after 7 and 28 days and results are presented in comparison with the control containing only cement (Fig. 3 and 4).

Analysis of charts 3 and 4 shows that flexural strength of FPA, FPN and FP biocomposites are higher compared to the control (without leather fibers), after 7 days by $27,1 \div 82,6 \%$, and 28 days, values are $24,8 \div 30,2 \%$ higher.

\section{Technology of Obtaining Biocomposites - Conceptual Model}

In order to make an accurate conceptual model a series of tools are used for modelling, among which the most frequently used is the entity-relationship diagram. 


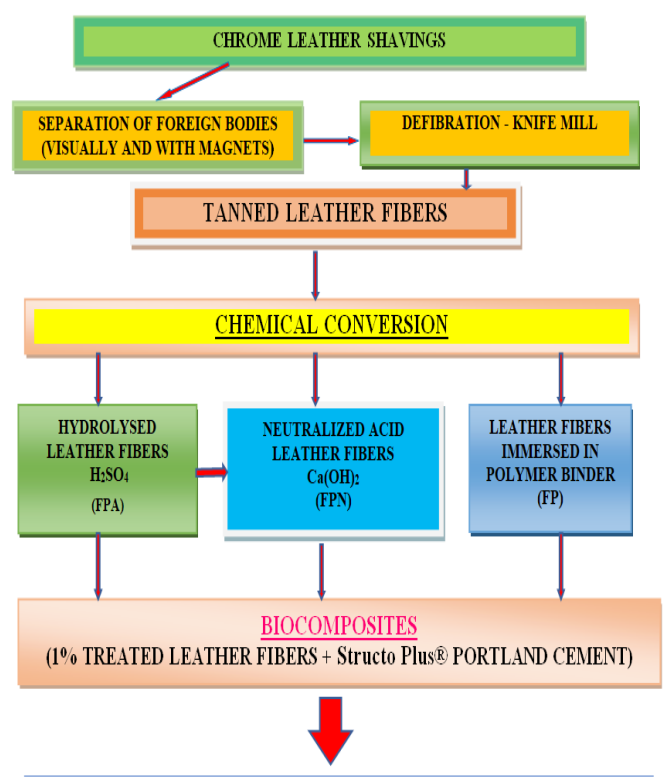

Figure 5. Technology for obtaining biocomposites with leather fibers - conceptual model

\section{CONCLUSIONS}

Experiments were carried out to obtain biocomposites from leather waste with applications in the building materials industry. Three kinds of fibres were obtained, namely acid-treated leather fibres (FPA), calcium hydroxide-neutralized leather fibers (FPN) and leather fibres immersed in a polymer binder (FP). Biocomposites were made by blending $1 \%$ of treated leather fibers and conventional Portland cement with the trade name Structo Plus ${ }^{\circledR}$.

The effect of adding chemically treated leather shavings on the characteristics and microstructure of biocomposites has been studied. The addition of low-pH treated leather waste (sulfuric acid) minimizes Portlandite formation and favours the formation of calcium sulphate.

The results obtained for mechanical strength (compressive and flexural strength) of FPA, FPN and FP leather fibers biocomposites both after 7 days and 28 days are higher than the control (no fibre).

In conclusion, the shavings waste resulting from leather processing can be used to obtain biocomposites with applications in the construction industry.

\section{Acknowledgment}

This work was financially supported by $\mathrm{MCl}$, in the frame of Nucleu Program 2018 project code PN 182301 03, "Bioconversion of leather waste into raw materials to obtain biocomposites with low environmental impact", contract no. $16 \mathrm{~N} / 16.03 .2018$.

\section{REFERENCES}

1. Sumita, D., Ashish, Y., Premendra, D., Mukul, D., Toxic hazards of leather industry and technologies to combat threat: a review, J Clean Prod, 2015, 87, 39-49, https://doi. org/10.1016/j.jclepro.2014.10.017.

2. Yilmaz, O., Kantarli, I.C., Yuksel, M., Saglam, M., Yanik, J., Conversion of leather wastes to useful products, Resour Conserv Recy, 2007, 49, 436-48, https://doi.org/10.1016/j. resconrec.2006.05.006.

3. Filibeli, A., Buyukkamaci, N., Senol, H., Solidification of tannery wastes, Resour Conserv Recy, 2000, 29, 251-261, https://doi. org/10.1016/S0921-3449(00)00050-1.

4. Fela, K., Wieczorek-Ciurowa, K., Konopka, M., Wozny, Z., Present and prospective leather industry waste disposal, Pol J Chem Technol, 2011, 13, 3, 53-55, http://doi.org/10.2478/ v10026-011-0037-2.

(C) 2018 by the author(s). Published by INCDTPICPI, Bucharest, RO. This is an open access article distributed under the terms and conditions of the Creative Commons Attribution license (http:// creativecommons.org/licenses/by/4.0/). 